\title{
The Treatment Effect of Highly Biocompatible Bismuth/ strontium/hydroxyapatite/chitosan for Osteosarcoma, Bacterial and Bone Defects
}

\author{
ZHIPENG HUANG, CHANG LIU, YANG LU, HAOYUAN SU, QINGLONG WANG, \\ CHANGMING ZHENG, RENPEI LU, KEGUAN SONG* \\ Department Orthopedics, The First Affiliated Hospital of Harbin Medical University, 150000, No. 23, Post Street, Nangang \\ District, Harbin, Heilongjiang, China
}

\begin{abstract}
Bi particles are dispersed in hydroxyapatite/ strontium/chitosan material by mixed coprecipitation and freeze-drying method. In oder to assess their anti-tumor, osteogenic and antibacterial effects, SEM, EDS, FIRT, XRD, hemolysis and swell experiments were used to assess the physical properties of the material. Cytotoxicity assays, PCR techniques were used to assess the effects of material on bone cells, osteosarcoma cells. Flow cytometry was used to evaluate the effect of composites on osteosarcoma cells, and the inhibitory effect of material on Staphylococcus aureus was evaluated by antimicrobial susceptibility test. The results show that Bi/Sr/CS/HA composites have better anti-tumor, anti-infective and osteogenic functions than Sr/CS/HA composites with increasing niobium concentration. Furthermore, by analyzing the results, it is believed that the addition of Bi in composite material play important roles in enhancing the antibacterial, antitumor and osteogenesis of the composite.
\end{abstract}

Keywords: Chitosan, strontium, hydroxyapatite, anti-tumor, osteogenesis, antibacterial

\section{Introduction}

Osteosarcoma is the most common primary malignant osteoma in orthopedics. The age of onset has two peaks, the first peak occurs in people under 24 years of age, which annual incidence rate is 4.4/100,000. The second peak occurs in people over the age of 59, with an annual incidence of 4.2/million.[1] It occurs in the femur, tibia and fibula, skull, jaw or pelvis [2,3]. Current treatments include surgery and combination chemotherapy. however, Surgical resection can remove tumor lesions, remain tumor cells around the resection site, and large surgical wounds can easily lead to bone defects and infections, serious cases even lead to truncated limbs [4]. Therefore, adjuvant chemotherapy, bone defect filling and systemic antibiotics are indispensable for killing residual tumor cells, preventing tumor recurrence, restoring local function and preventing postoperative infection. However, these treatments have serious side effects. Therefore, biocompatible particles, which have tumor growth inhibition effects, fill of bone defects and bactericidal effects, have great potential in meeting the above requirements.

Studies have shown that the incorporation of metallic materials into matrix composites not only maintain original function, imparts a new function to the materia [5-8]. Nanomaterials have been researched in different fields and have developed promising properties with broad application prospects such as carrying genes and drugs [9,10], photodynamics and photothermal effects [11], and antibacterial properties [10,12]. Calcium phosphate ceramic material can form a strong osseointegration with natural bone, which has good biocompatibility and biological activity, and for the reason that it is an ideal substitute material for bone tissue. Utilizing these versatility and highly desirable features, multifunctional composites are currently used in drug delivery [13], biosensors, bioimaging 14], infection therapy [10] and oncology [11]. For example, hydroxyapatite (HA), which is the main component of natural bone, has been widely used in many fields such as spinal fusion, craniofacial reconstruction, bone defect and fracture treatment due to its excellent performance [15].

\footnotetext{
*email: songkeguan@sohu.com
} 
Chitosan (CS) is biodegradable has good biocompatibility and antibacterial properties [16]. Additionally, the chitosan hydrogel can be mixed with other materials, eg, hydroxyapatite(HA),for tissue engineering.

Bismuth $(\mathrm{Bi})$ is a widely used ingredient in many medicines. for example, Bi subsalicylate is used for anti-Helicobacter pylori infection [17] and thiol for the treatment of opportunistic pathogens Pseudomonas aeruginosa infectio [18,19]. It is also used to treat eye infections such as the brocathol Bi-HA stent, which exhibits excellent antimicrobial activity and improves biodegradability for various human pathogens [20]. Studies have shown that Bi in M-HA inhibits the function of neoplastic osteoblasts, improves the osteogenic capacity of healthy osteoblasts, and histological observations show good osseointegration [21].

In order to better achieve our desired purpose, we added metallic strontium ( $\mathrm{Sr}$ ) to the materia, strontium can promote osteoblast differentiation, gene expression and functional activities, inhibit osteoclast proliferation, thereby promote bone regeneration and inhibit bone resorption, promote early bone healing and bone ingrowth, achieve long-lasting healing. The Sr concentration doesn't change for bone resorption in the concentration range of 1-12 mM, while in the range of 0.1-1 mM, alkaline phosphatase (ALP), osteocalcin (OCN), and bone formation increase with concentration increasing [22]. Studies have shown that $\mathrm{Sr}$ ions released by the composite scaffold can increase cell proliferation and osteogenic differentiation, and the Sr/HAP/CS nano hybrid scaffolds have optimal osteoinductivity dues to the synergistic effect between $\mathrm{Ca}^{2+}$ and $\mathrm{Sr}^{2+}$ ions. The ALP activity is gradually rising with the increase of the $\mathrm{Sr} / \mathrm{Ca}$ ratio in $\mathrm{Sr} / \mathrm{HA}$, and reaching the maximum when the $\mathrm{Sr} / \mathrm{Ca}$ ratio was 1:1[23].

In view of the excellent properties of these composites, our strategic goal and work is to combine the advantages of several materials and combine them together, So that it can play a better role in inducing osteosarcoma cell apoptosis, promoting the growth of osteoblasts and antibacterial properties by decorating different $\mathrm{Bi}$ concentrations but with a $\mathrm{Ca} / \mathrm{Sr}$ ratio of $1: 1 \mathrm{Sr} / \mathrm{CS} / \mathrm{HA}$ composite. The physico-mechanical properties, anti-tumor properties, bone growth and antimicrobial properties of the prepared scaffolds are extensively characterized and evaluated. The biological properties of decorative composite material is studied by a series of numerous in vitro methods, for example, Cell activity assay, PCR, flow cytometry. The physicochemical characteristics and initial findings in vitro studies support the proposed potential role of inducing apoptosis, promoting osteoblast growth and bactericidal.

\section{Materials an methods}

Chitosan was purchased from Aoxing Biomedical Company (shanxi, China); CCK-8 (Toshihito, Japan; High glucose DMEM medium (Hyclone, Peptide bovine serum (Hyclone ; 0.25\% trypsin (biolegend bioscience; serum (imported); ANNEXIN V-FITC/PI (Solebao,china). The reagents used in the synthesis of materials in this study are all purchased analytical reagents.

\subsection{Synthesis of composite materials}

CS powder $(4.0 \mathrm{~g})$ was dissolved in an acetic acid solution $(100 \mathrm{~mL}, 2.0 \% \mathrm{v} / \mathrm{v})$ and stirred in a $50^{\circ} \mathrm{C}$ water bath. The mole ratio of $\mathrm{Ca}(\mathrm{OH})_{2}$ and $\mathrm{SrCl}_{2}$ is $1: 1$, the mole ratio of $\mathrm{Ca}(\mathrm{OH})_{2}$ and $\mathrm{SrCl}_{2}$ to $\mathrm{Bi}\left(\mathrm{NO}_{3}\right)_{3} \cdot 5 \mathrm{H}_{2} \mathrm{O}$ is 1:1:0, 1:1:0.5, 1:1:1, 1:1:2 mix the above substances into the $\mathrm{CS}$ solution in a $50^{\circ} \mathrm{C}$ water bath and mix well, slowly add K2HPO4 (maintain $(\mathrm{Ca}+\mathrm{Sr}) / \mathrm{P}=1.67)$, add $\mathrm{NaoH}$ dropwise, maintain $p \mathrm{H}$ about 10 , wash three times and added to a 24 -well plate, store at $-80^{\circ} \mathrm{C} 24 \mathrm{~h},-60^{\circ} \mathrm{C}$ freezedried for $48 \mathrm{~h}$. the synthesized materials are recorded as B0, B1, B2, B3.

\subsection{Physical characterization of biological materials}

2.2.1. Morphological characterization of the composite structure by scanning electron microscopy. Briefly, the material was adhered to a copper target, and the sample was sputter coated with gold and analyzed under a Quanta 200 environmental scanning electron microscope (USA). The Energy 
Dispersive Spectrometer (EDS) is used to detect the type and content of constituent elements in the material microdomain.

2.2.2. The composition of the chemical functional groups of the composite was obtained by FTIR (Nicolet 6700, Thermo Fisher Scientific).The grinded powder of each scaffold was mixed with potassium bromide by $1 / 150$ weight ratio for $15 \mathrm{~min}$ and compressed into particles. Each infrared spectrum is the average of 32 scans collected at room temperature at $2 \mathrm{~cm}^{-1}$ resolution. Infrared spectra were obtained using a Bruker Vertex 70 FT-IR spectrometer.

2.2.3. Study the content of the phase in the material support by X-ray diffractometer (XPS, Japan). The abrasive material is placed on the glass sheet and scanned with the following parameters: angle $20^{\circ}-70^{\circ}$, wavelength $0.154 \mathrm{~nm}$, speed $0.1 \mathrm{~s} / \mathrm{step}$, and analyzed by OMNIC.

2.2.4. Evaluated the swell behavior of the stent based on Fonseca-Garca Abril's study[24]. Briefly, Dry scaffolds with a volume of (1-2) x (4-5) x (4-5) mm were used.the dry weight of the scaffold material was recorded, then the scaffold was immersed in $37^{\circ} \mathrm{C}$ phosphate buffered saline (PBS), the wet weight was recorded for 1 hour, $24 \mathrm{~h}$, and the surface moisture was removed using absorbent paper. Measure the size of the bracket with a micrometer. The weight and volume expansion of the structure (sw and sv, respectively) are determined according to the following equations:

$$
\text { Swell ratio }=(\text { wet weight }- \text { dry weight }) / \text { dry weight }
$$

2.2.5. In vitro hemolysis experiments were carried out on the basis of $\mathrm{Lu}$ yao's research and modification [25]. Briefly, the blood of volunteers containing EDTA was taken and $15 \mathrm{mg}$ of powder grinded from different materials were placed in diluted blood of $1 \mathrm{~mL}$ of normal saline and incubated at $37^{\circ} \mathrm{Cfor} 30 \mathrm{~min}$. The positive and negative controls were $1 \mathrm{~mL}$ of deionized water add $0.2 \mathrm{~mL}$ of diluted blood. the mixture was incubated in a warm water bath at $37^{\circ} \mathrm{C}$ for $60 \mathrm{~min}$. The tube was centrifuged at $500 \mathrm{~g}$ for $10 \mathrm{~min}$, and $100 \mu \mathrm{L}$ of the supernatant was transferred to a 96-well plate. Optical density (OD) was measured at $545 \mathrm{~nm}$. The hemolysis rate (IR) was calculated by the following formula.

$$
\mathrm{IR}=(\text { ODsample }- \text { ODcontrol (-) ) / (OD control (+) - ODcontrol (-) ) } \times 100 \%
$$

\subsection{In vitro studies}

\subsubsection{Cell proliferation and cytotoxicity}

CCK-8 detects cellular activity. The MC3T3-E1 or MG-63 cells were digested with $0.25 \%$ trypsin, centrifuged, and diluted into a single cell suspension with DMEM. These cells were seeded into 96well plates at $2 \times 104$ cells per well $(100 \mu \mathrm{L}$ per well), and after incubation for $24 \mathrm{~h}$ in the incubator, $100 \mu \mathrm{L}$ of different concentrations of the composite extract were added to the cells, $100 \mu \mathrm{L}$ blank extract were added to the control group and each condition was repeated 3 Times. After $24 \mathrm{~h}, 3$ days, and 7 days of culture, $100 \mu \mathrm{L}$ of a $10 \%$ CCK-8 solution was added to all wells. After further incubation at $37^{\circ} \mathrm{C}$, the optical density (OD) of each well was examined to analyze the cell viability. The formula for these ratios is as follows:

$$
\begin{gathered}
\text { Survival rate }=(\text { OD experimental group }- \text { OD blank well }) /(\text { OD control group }- \text { OD blank } \\
\text { well }) \times 100 \%
\end{gathered}
$$

\subsubsection{Real-time polymerase chain reaction(RT-PCR)}

Osteogenic related genes ALP, runt-associated transcription factor 2 (Runx2), OCN and osteogenin (OPN) and apoptosis-related matrix genes cas-3 (casepase-3), cas-9 (casepase-9) , MMP-9 (matrix 
metallopeptidase 9) were assessed using real-time PCR. In the material extract cultured osteoblast MC3T3-E1 for 14 days and osteosarcoma cell MG63 for 3 days. Total RNA in cells was isolated by cleavage in Trizol. PCR was performed using a Brilliant SYBR Green QPCR Master Mix (TakaRa) and a Light Cycler instrument (ABI 7900HT). The PCR cycle included 40 cycles of amplification template DNA, and the primers were annealed at $60^{\circ} \mathrm{C}$. The relative expression level of each target gene was then calculated using the 2- $\Delta \Delta \mathrm{Ct}$ method. The amplification efficiency of the primer pair was verified to achieve a quantitative comparison of gene expression. All primer sequences were from related studies $[6,25]$ and are summarized in Table 1 . The PCR was performed at least 3 times, and the result was normalized to the target gene expression of the reference gene GPDH. This error reflects the standard deviation of the mean of the technique.

\begin{tabular}{|c|c|c|}
\hline \multirow{2}{*}{$\begin{array}{c}\text { Gen } \\
\mathrm{e}\end{array}$} & \multicolumn{2}{|c|}{ Gene sequence } \\
\hline & Forward & Reverse \\
\hline CAS-9 & $5^{5}$-СTTCGTTTCTGCGAACTAACAGG-3' & 5-GCACCACTGGGGTAAGGTT-3 \\
\hline CAS-3 & 5-CATGGAAGCGAATCAATGGACT-3' & 5-CTGTACCAGACCGAGATGTCA-3' \\
\hline MMP-g & $5^{5}$-CCTGGAGACCTGAGAACCAATC-3' & 5'-GTCTCGGGCAGGGACAGTT-3' \\
\hline ALP & 5-GCTACACCACAACACGGGCGA-3, & 5-TCCAAATGCTGATGAGGTCCA-3 \\
\hline OPN & 5-TGAGACTTGCAGTGATTTGCTTTTGC-3 & 5-CTCATCTGTGGCATGGGGATACTG-3 \\
\hline GAPDH & 5-ACCACAGTCCATGCCATCAC-3 & 5-CCACCACCCTGTTGCTGTA-3 \\
\hline RUNX2 & $5^{5}$-TCCAACCCACGAATGCACTA-3' & 5'-GAAGGGTCCACTCTGGCTITG-3' \\
\hline$O C N$ & $5^{\prime}$-CAATAAGGTAGTGAACAGAC-3' & $5^{5}$-CTTCAAGCCATACTGGTCT-33 \\
\hline
\end{tabular}

\subsubsection{Annexin V/propidium iodide (PI) staining}

osteosarcoma MG63 cells were seeded at 1 x 106 cells/ml into 6-well plates (Becton Dickinson, USA). A total of $1 \mathrm{~mL}$ of different concentrations of cell suspension was added to each well. After 24 $\mathrm{h}$ of the cell attachment, the material extract was added in. After $72 \mathrm{~h}$ of incubation at $37^{\circ} \mathrm{C}$, the cell suspension of each well was collected, centrifuged at $1000 \mathrm{r} / \mathrm{min}$ for $5 \mathrm{~min}$, and the supernatant was discarded. $1 \mathrm{~mL}$ of cold PBS was added to the cell pellet and gently shaken to resuspend the cells. Centrifuge at $1000 \mathrm{r} / \mathrm{min}$ for $5 \mathrm{~min}$ and discard the supernatant. These washing steps were repeated twice. The cells were then resuspended in $200 \mu \mathrm{L}$ of PBS, and $10 \mu \mathrm{L}$ of fluorescein isothiocyanate (FITC)-labeled annexin V (Annexin V-FITC) and $5 \mu \mathrm{L}$ of PI (solarbio, CA1020) were added. The mixture was gently mixed, incubated in the dark for $15 \mathrm{~min}$ at room temperature, adjusted to a volume of $500 \mu \mathrm{L}$ with PBS, and the level of apoptosis was measured by flow cytometry (Beckham Coulter, USA). All experiments were repeated three times.

\subsubsection{Antibacterial activity}

Staphylococcus aureus (ATCC25933), the most common staphylococcus aureus, was selected for the antibacterial zone test to determine the antibacterial properties of the materials. The bacteria preserved at $4^{\circ} \mathrm{C}$ were inoculated into the mushroom broth and incubated at $37^{\circ} \mathrm{C}$ overnight. Several test tubes containing $5 \mathrm{~mL}$ normal saline were taken. Appropriate amount of fresh bacterial broth was taken in sterile normal saline tube, and the concentration of bacteria was adjusted to $1 \times 108 \mathrm{CFU} / \mathrm{mL}$ with turbidimeter. $100 \mathrm{~L}$ bacterial broth was taken on AGAR plate with pipette. Each scaffold was 
ground into powder, and $3 \mathrm{mg}$ of each scaffold was placed on a plate, incubated at $37^{\circ} \mathrm{C}$ for $24 \mathrm{~h}$. Measure a clear area (inhibition area). All experiments were repeated three times. The whole operation is carried out in a biosafety cabinet to prevent contamination by bacteria.

\subsection{Statistical analysis}

The experimental data were analyzed by GraphPad Prism 6.0 software. The results were expressed as mean \pm standard deviation. The significant difference was analyzed by one-way analysis of variance (ANOVA). When the significant difference value $\mathrm{P}<0.05$, the difference was statistically significant, among which $* \mathrm{P}<0.05, * * \mathrm{P}<0.01, * * * \mathrm{P}<0.001$, **** $\mathrm{P}<0.0001$.

\section{Results and discussions}

\subsection{Scanning electron microscopy (SEM)}

The external morphology of the composite were investigated by SEM analysis (Figure 1). Figure 1 (a-d) shows the interaction in the scaffold. The connected pores and the interconnected porous structure may facilitate the transfer of the tissue fluid. However, although our material has a certain structure after lyophilization, but the mechanical strength is insufficient and the brittleness is relatively large, the study is to synthesize the composite material. The crystal structure and orientation are different. The EDS spectrum of the B3 scaffold was determined (Fiure 1e), and it was found that the $(\mathrm{Ca}+\mathrm{Sr}) / \mathrm{P}$ of the doped sample was similar to the $\mathrm{Ca}+\mathrm{Sr} / \mathrm{P}(1.60-1.70)$ of the bioapatite[27].

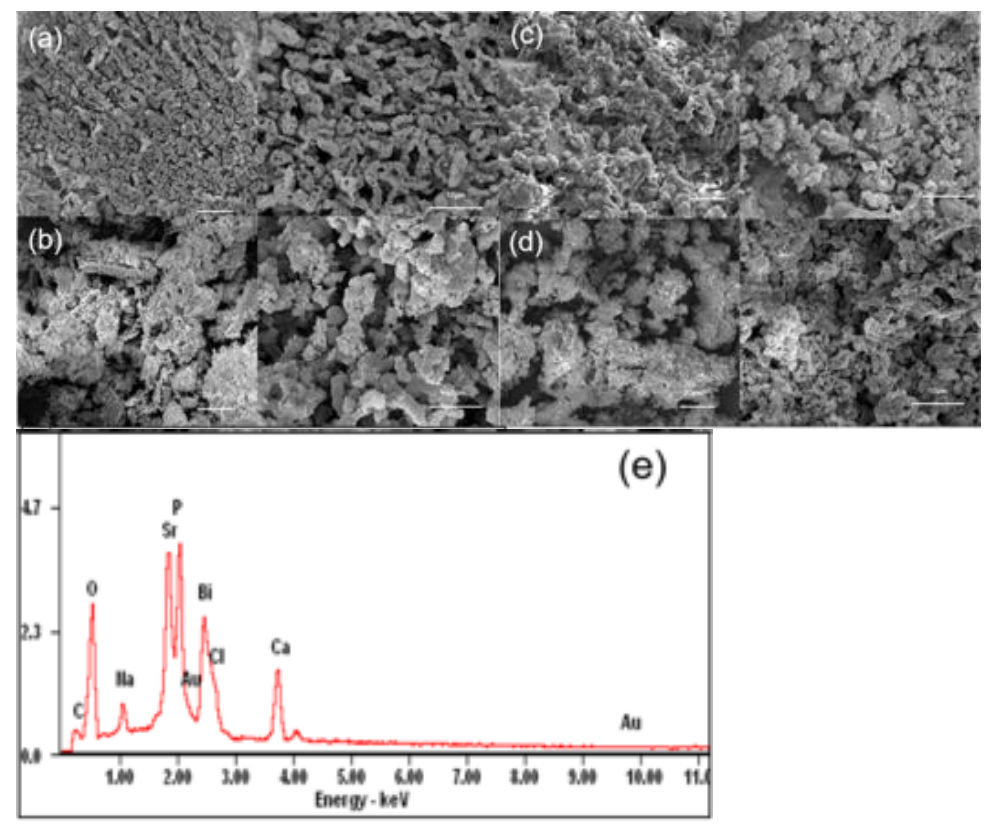

Figure 1. SEM showed the morphology and structure of the composites.(a) BO; (b) B1; (c) B2;

(d) B3; (e) EDS. Spectrum

Dysplays Elemental Composition of Materials

\subsection{X-ray diffraction pattern (XRD)}

The XRD patterns of the Sr/CS/HA and Bi/Sr/CS/HA scaffolds were shown in Figure $2 \mathrm{~A}$. The XRD of the CS/HA composite material indicated that the diffraction peaks were at $25.3^{\circ}, 27.22^{\circ}$, $31.6^{\circ}, 45.3^{\circ}$ corresponding to Separate values of chitosan and nano-hydroxyapatite. The X-ray diffraction pattern of the $\mathrm{Bi} / \mathrm{Sr} / \mathrm{CS} / \mathrm{HA}$ stent showed three peaks corresponding to various compounds. In addition, the crystallization peaks of chitosan and HA in the composite indicated that the addition of $\mathrm{Bi}$ alloy nanoparticles did not change the crystalline properties of the CS/HA matrix. There is a slight change in the position of the peak because of the addition and concentration change of strontium.

\subsection{Fourier transform infrared spectroscopy}

The FT-IR analysis of the biocomposite scaffold and individual components was shown in Figure 2B. In the composite species, the peak at $3420 \mathrm{~cm}^{-1}$ indicated the presence of $\mathrm{NH} 2$ groups, and in B0 
$1667 \mathrm{~cm}^{-1}$ was attributed to the presence of amide I, and $1789 \mathrm{~cm}^{-1}$ in $\mathrm{B} 1-3$ was attributed to the presence of amide I, mainly due to the existence of two Bi and $\mathrm{Sr}$. The peak at the peak of $1350 \mathrm{~cm}^{-1}$ indicated the presence of amide II. The FT-IR spectrum of HA showed peaks at $1435 \mathrm{~cm}-1$ and 736 $\mathrm{cm}-1$, which corresponded to the $-\mathrm{OH}$ stretching and bending vibration modes, and the peak at 1019 $\mathrm{cm}-1$ indicated the presence of phosphate groups [25]. The spectrum of $\mathrm{Bi} / \mathrm{Sr} / \mathrm{CS} / \mathrm{HA}$ material retained all characteristic peaks of $\mathrm{CS}, \mathrm{HA}$ and $\mathrm{Bi} / \mathrm{Sr}$, indicating that $\mathrm{CS}, \mathrm{HA}, \mathrm{Bi} / \mathrm{Sr}$ might be associated with $\mathrm{NH} 2$ group chitosan, leading to characteristic peaks of $\mathrm{NH} 2$ from $3610 \mathrm{~cm}^{-1}$ shifted and a peak appeared at $3420 \mathrm{~cm}^{-1}$. In addition, the composites showed peak in $813 \mathrm{~cm}^{-1}$, probably due to the presence of nitroso in the material fabrication process.

\section{4. scaffolding for swelling studies}

It is well known that the ability of cells to adhere to the surface of foreign bodies is a good indicator of compatibility, and cell adhesion behavior is considered to be an important part of understanding the biocompatibility of materials [26]. Therefore, the properties of the composite determine cell adhesion, orientation, attachment, migration and metabolism.

The water absorption of composite materials is one of the important properties of materials in bone tissue engineering and one of the important characteristics of cell adhesion [27].

Swelling studies showed that the volume expansion of B0 and b1, B2 and B3 scaffolds did not change significantly. From the results of material characterization, it can be seen that the volume of the scaffolds did not change after treatment. And there was no significant difference in swelling ratio between B0 and B1, B2, B3 composites during the 1hour incubation period, but as the bismuth was added, the pores increased and the degree of swelling varied. When the incubation time was maintained for $24 \mathrm{~h}$, the B1, B2, B3 composite retained more water than its initial weight compared to the B0 stent, and the degree of swelling rose with the bismuth increasing (Figure 2C). This indicated that the addition of bismuth results in a faster water absorption capacity, which leads to an increase in the pore size, facilitates a rapid increase in water content and cell infiltration, resulting in better bone tissue ingrowth.
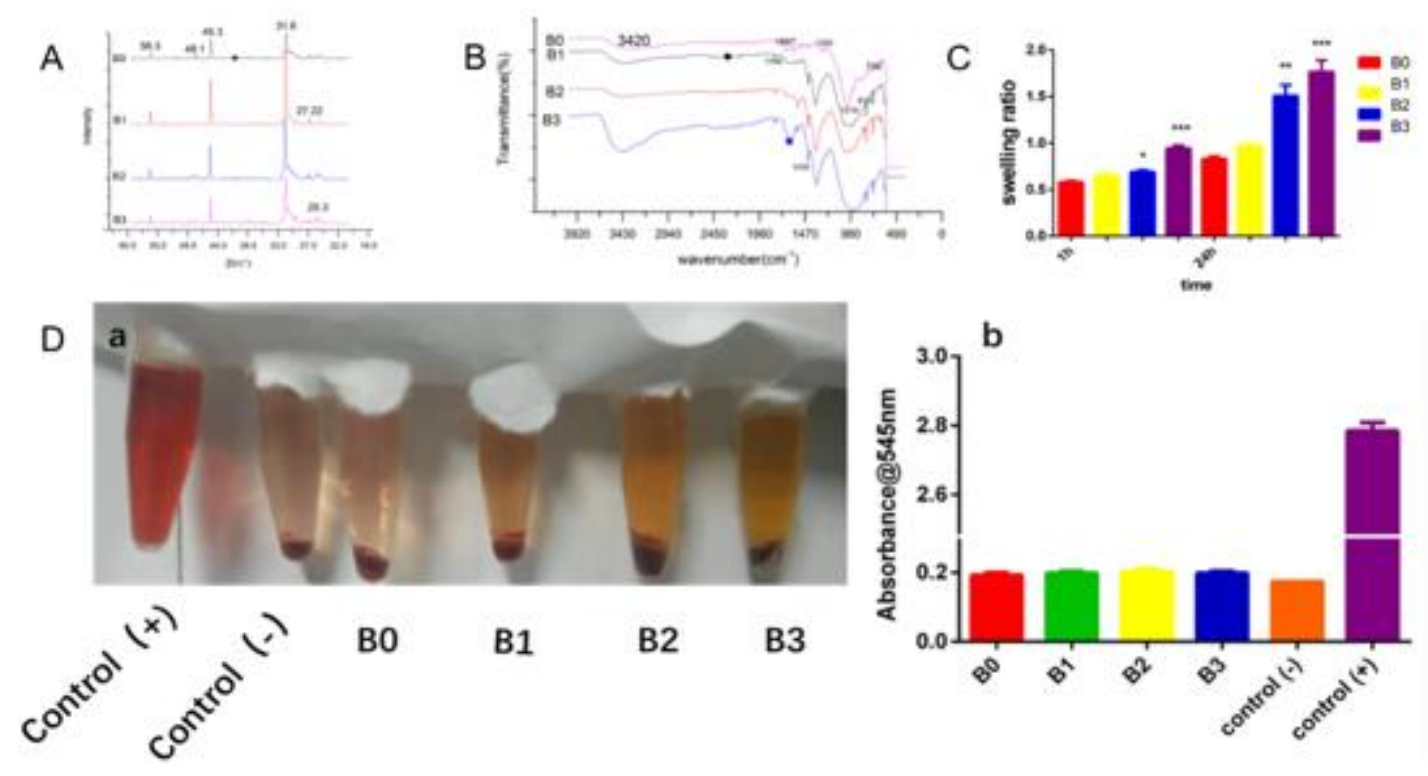

Figure 2. (A). X-ray Diffraction of Materials; (B). Infrared Spectra of Materials. (C) .The swelling behavior of the material in PBS. (D). Hemolysis test. (a) The general observation image of hemolysis experiment of materials; and (b) OD value after the interaction of materials and blood. The data are expressed as mean $+\mathrm{SD}, * \mathrm{P}<0.5, \quad * * \mathrm{P}<0.01, * * * \mathrm{P}<0.001$ 


\subsection{Hemolysis experiment}

Blood compatibility is another important issue in biomaterials, and good materials should not cause blood cell rupture. The OD values of the positive control (deionized water), negative control (PBS) and samples are shown in Figure 2Da, respectively. Clearly, the positive control caused hemolysis and red solution due to the release of hemoglobin. For the scaffold and the negative control, the supernatant was clear, indicating that the scaffold had no hemolysis on human erythrocytes (Figure 2D b). The results show that the color change between the centrifuge tubes between the respective groups is mainly due to the change in the concentration of Bi ions. By calculating the B0-B3 hemolysis rate after $60 \mathrm{~min}$ is $0.72 \%, 0.94 \%, 1.12 \%, 0.97 \%$, which is significantly less than $5 \%$ of the international hemolysis standard, so the prepared material has no hemolysis risk.

\subsection{Cell activity}

The proliferation of MC3T3E1 cells on B0, B1, B2, B3. Compared with the B0 nanoparticles, the growth rates of the $\mathrm{B} 1, \mathrm{~B} 2$, and $\mathrm{B} 3$ nanoparticles increased at 1,3 , and 7 days (Figure 3A a). Therefore, it is apparent that B0,B1,B2,B3 nanoparticles have an important influence on cell proliferation of MC3T3E1 cells, because $\mathrm{Bi}$ and $\mathrm{Sr}$ are known to increase bone cell activity[29][30]. This clearly shows that in the sr/cs/ha nanoparticles, the rational distribution of the bi-substituents can modify the biological function of the composite [31].
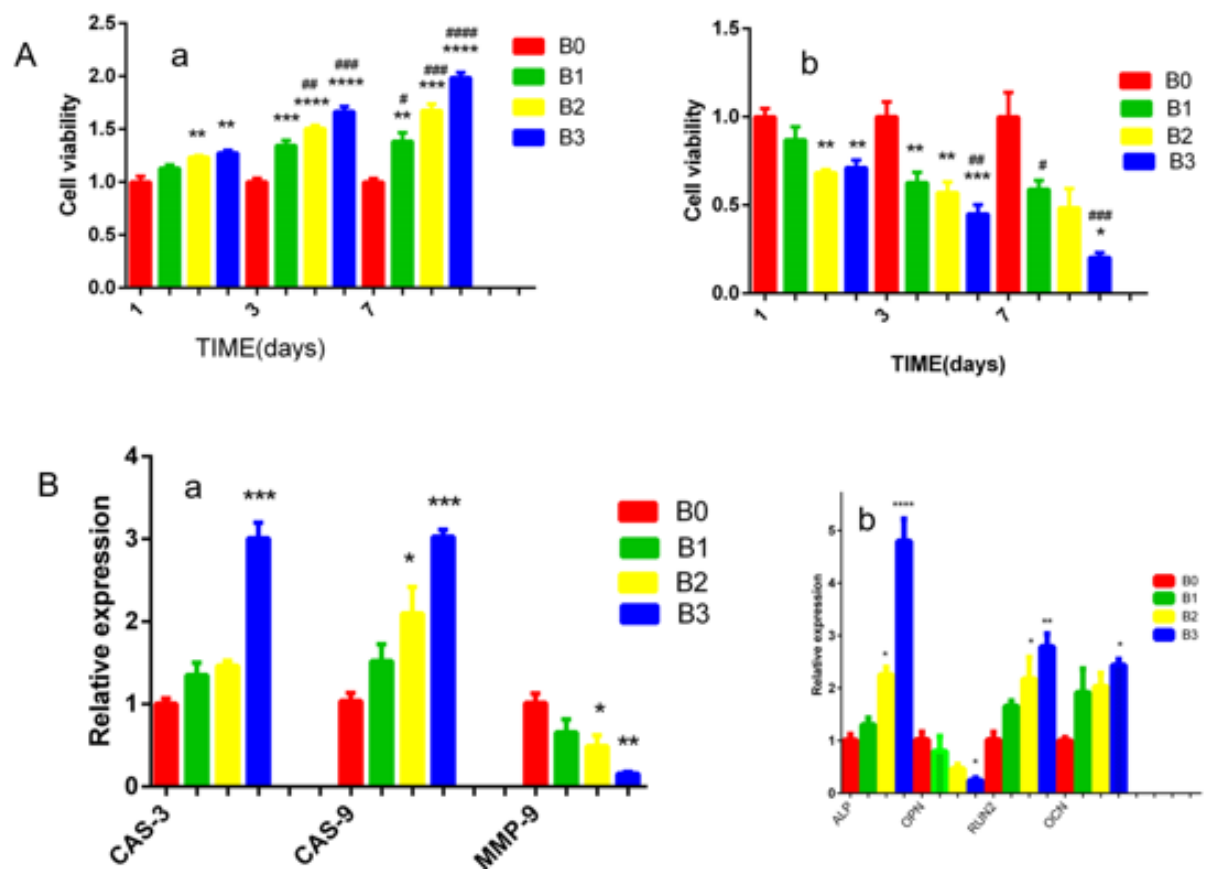

Figure 3. The effect of materials on cells. (A) a) After incubation for 1, 3 and 7 days, different concentrations of $\mathrm{Bi}$ affected the survival rate of MC3T3E1 cells; .b) The cytotoxicity of different materials on MG63 cells was determined after incubation for 1, 3 and 7 days. (B) (a) The relative expression of apoptosis-related genes in osteosarcoma cells and materials after 3 days of culture. (b) The relative expression level of osteoblast-related genes between materials and osteoblasts cultured for 14 days. In each case, the data were standardized as GAPDH expression levels as housekeeping genes. Data are marked as mean $+\mathrm{SD} ; * \mathrm{P}<0.5$, *** $\mathrm{P}<0.01$, *** $\mathrm{P}<0.001$, , $* * * * \mathrm{P}<0.0001$. Compared with $\mathrm{B} 0 ;{ }^{\#} \mathrm{P}<0.5,{ }^{\# \#} \mathrm{P}<0.01,{ }^{\# \#} \mathrm{P}<0.001,{ }^{\# \# \#} \mathrm{P}<0.0001$. Compared to 1 days in the same group

The anti-cancer effect of the synthesized $\mathrm{Bi} / \mathrm{Sr} / \mathrm{CS} / \mathrm{HA}$ on osteosarcoma MG63 cells was tested using the cck-8 kit. The Bi/Sr/CS/HA particles were dose-dependently cytotoxic to MG63 cells (Figure 
3A-b), which was the first report of the effect of Bi-substituted chitosan hydroxyapatite nanoparticles incubated with MG63 cells 1, 3 and 7 days. The cytotoxic effect of B3 nanoparticles on MG63 cells was greatest at the bismuth concentration, which was the strongest at 7 days. The cytotoxicity of the nanoparticles is attributed to the presence of $\mathrm{Bi}$ in $\mathrm{Sr} / \mathrm{CS} / \mathrm{HA}$. Its anti-tumor effect is not only direct and selective, but also dose-dependent. This result was supported by flow cytometry (Figure 5A), we demonstrated that the late apoptosis and necrosis of cancer cells have increased after 3 days of culture of Bi nanoparticles (Figure 5B). Therefore, the proprietary nature of B3 (i.e., small size and similar large surface area near the surface) may cause biological effects that is far from other particles. This experiment revealed that $\mathrm{Bi} / \mathrm{Sr} / \mathrm{CS} / \mathrm{HA}$ has different toxicity to two different bone-joining cells, less toxicity to MC3T3E1 normal osteoblasts, and greater toxicity to MG63 tumor bone cells. This is because bismuth in the scaffold has selective antineoplastic activity, which can change the plasma membrane and reduce its permeability when it enters the tumor cells. Once internalized, genomic DNA is destroyed by direct interaction, and bismuth is nontoxic in normal cells [32].

\subsection{Gene expression}

PCR detects gene expression involved in bone formation in ALP, RUN2, OCN and OPN. Evaluation of CAS3, CAS9, MMP9 and related tumor cell apoptosis. The highest mRNA levels were detected in cells grown on B3 by ALP, RUN2, OCN, CAS3, CAS9 genes, while the lowest mRNA levels were detected in cells grown on $\mathrm{Sr} / \mathrm{CS} / \mathrm{HA}$. Therefore, the results of osteoblast gene expression indicate that mineral $\mathrm{Bi}$ in $\mathrm{B} 3$ is more able to support the differentiation of MC3T3E1 cells than $\mathrm{Sr} / \mathrm{CS} / \mathrm{HA}$ (Figure 3B-b). Increased expression of apoptosis-related genes indicates increased apoptosis of tumor-induced osteoblasts.

The results showed that replacing Bi with $\mathrm{Sr} / \mathrm{CS} / \mathrm{HA}$ has improved biocompatibility and excellent cell viability compared to Sr/CS/HA particles, excellent cell compatibility was attributed to the chemical composition and porous structure of the scaffold. First, the $\mathrm{Sr}, \mathrm{CS}, \mathrm{HA}$ in the Bi/Sr/CS/HA composite material is similar to the bioapatite in the chemical composition and crystal structure, providing a suitable environment for supporting cell adhesion and proliferation [33, 34]. Secondly, CS derived from the crustacean hard shell has good biocompatibility and biodegradability, which not only can improve cell adhesion and proliferation, but also increase the expression of RUNX2 and ALP mRNA[35, 36]. RUNX2 is a key transcription factor involved in osteoblast differentiation. It promotes the expression of osteogenic genes in early stage, regulates cell cycle progression, improves the bone microenvironment, and affects the function of chondrocytes and osteoclasts [37,38]. Third, the incorporation of $\mathrm{Sr}$ in cs/HAP has no significant effect on adhesion, diffusion and morphology of bone cells, but plays an important role in proliferation and the like. $\mathrm{Sr}^{2+}$ ions have been shown to interact with calcium-sensitive receptors $(\mathrm{CaRs})$ in MC3E3T1 cells, thereby enhancing the mRNA levels of genes that regulate osteoblast proliferation [39]. The synthetic $\mathrm{Bi} / \mathrm{Sr} / \mathrm{CS} / \mathrm{HA}$ nanoparticles therefore have great potential in bone tissue applications.

In this study, we studied the effects of bismuth additives on osteosarcoma cells, although there is no relevant study on bismuth metal-induced apoptosis of osteosarcoma cells. Expression of apoptosisrelated genes such as cas-9 and cas-3 was significantly upregulated (Figure 3B-a). Caspase-9 is proteolytically activated and activates caspase-3, leading to the division of specific intracellular proteins, which ultimately leads to cell death [25]. Up-regulation of these pro-apoptotic genes suggests that B3 scaffolds promote tumor cell apoptosis by activating mitochondrial endogenous pathways, thereby inhibiting tumor growth and recurrence. Our results confirm that bismuth induces apoptosis by activating the caspase- 3 signaling pathway.

MMP-9 has an effect on gelatin or collagen and is associated with osteosarcoma invasion behavior[40]. As shown in the figure above, compared with the Sr/CS/HA scaffold, the expression of MMP-9 in the B2-B3 scaffold decreased with the concentration increasing, the difference was statistically significant $(\mathrm{P}<0.05)$. Therefore, B3 material nanoparticles are much better than $\mathrm{Sr} / \mathrm{CS} / \mathrm{HA}$ 
material, stimulating osteoblast differentiation and proliferation, inhibiting osteosarcoma cell proliferation, and affecting cell gene expression.

$\mathrm{Bi}$ addition in the composite not only inhibits the function of osteosarcoma cells, promotes the apoptosis of osteosarcoma cells, but also promotes the function of osteoblasts, which is consistent with previous studies. Previous studies have proved good osseointegration through in vivo experiments. [41]. In summary, we believe that bismuth can induce apoptosis of osteosarcoma cells through caspase pathway. First, caspase- 9 is activated in the apoptotic pathway, then caspase- 3 downstream is activated through a series of reactions, which eventually leads to accounting breakdown and apoptosis (Figure 4).

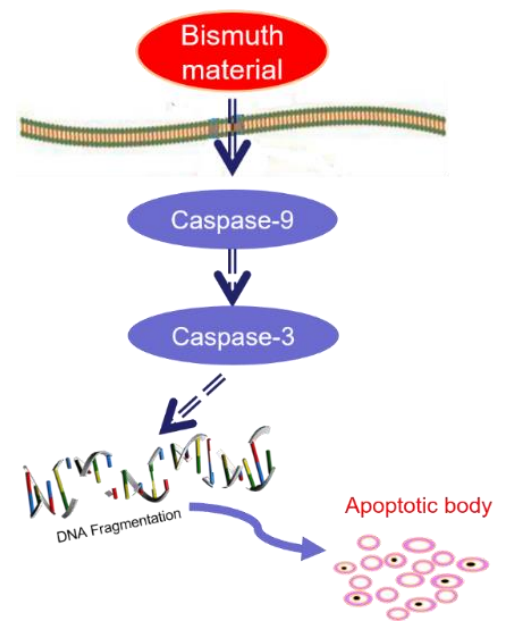

Figure 4. Schematic diagram of the mechanism of action of $\mathrm{Bi}$ on osteosarcoma cells

\subsection{Detection of apoptosis}

For quantitative analysis, apoptosis was determined using flow cytometry using the FITC-Annexin V/PI assay. Compared with $\mathrm{Sr} / \mathrm{CS} / \mathrm{HA}, \mathrm{Bi} / \mathrm{Sr} / \mathrm{CS} / \mathrm{HA}$ induced apoptosis more effectively, and the percentage of apoptosis increased from $5.2 \%$ to $18.4 \%$ (Figure $5 \mathrm{~A}$ ). As the concentration of bismuth increased, the percentage of apoptosis increased from 6.2 to $18.4 \%$. On the other hand, with the increase of bismuth concentration, early apoptotic cells and late apoptotic cells and necrotic cells increased in different proportions, while the proportion of late apoptotic cells and necrotic cells increased significantly. So it can be concluded, B3 material is the most effective material for promoting apoptosis, which may be attributed to the endocytosis of nanoparticles to produce cell granules through cells (Figure 5B).
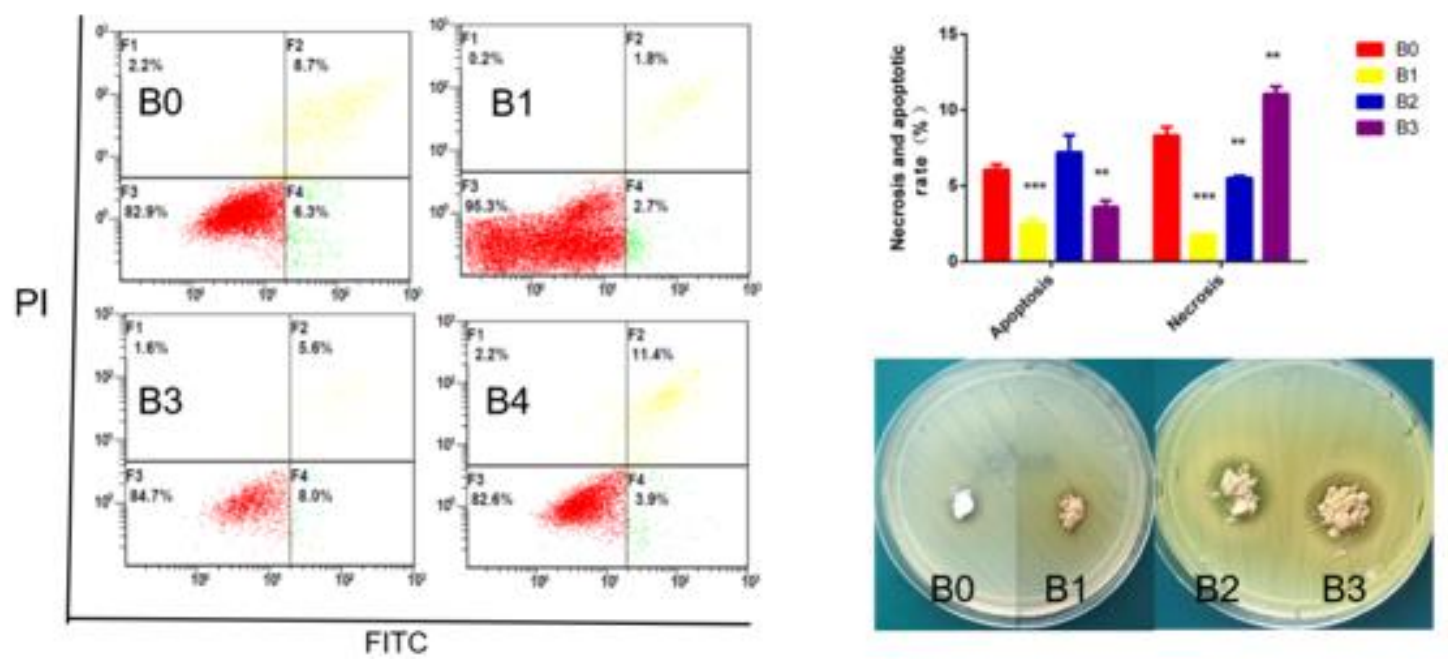

Figure 5. (A) Flow cytometry was used to analyze the apoptosis and necrosis of osteosarcoma cells cultured on different scaffolds for 3 days. (B) The rate of necrosis and apoptosis of osteosarcoma cells

in stents. (C) Inhibitory effect of different materials on Staphylococcus aureus, the same scale of inhibitory ring was used. Data are marked as mean $+\mathrm{SD} ; * * \mathrm{P}<0.01$, $* * * \mathrm{P}<0.001$, Compared with $\mathrm{B} 0$ 


\subsection{Scaffold antibacterial activity}

Simple and effective study of the release of bactericidal and antibacterial ability by bacterial inhibition ring test. The addition of the antibacterial activity of the Sr/CS/HA material was examined by inhibition zone using S. aureus strains. The regional inhibition of B0, B1, B2, and B3 scaffolds against Staphylococcus aureus were found in the Figure 5C. It should be noted that the antibacterial activity of $\mathrm{B} 0$ is due to the inherent antibacterial properties of chitosan. When the B0 particles were used for antibacterial activity, we found that B0 was an inert material and had no antibacterial activity. Therefore, the increase in the microbial inhibition zone observed by the $\mathrm{Bi} / \mathrm{Sr} / \mathrm{CS} / \mathrm{nHAp}$ composite is due to the presence of Bi particles.

Chitosan alters cell permeability by interacting with cell membranes, also acts as a chelating agent to selectively bind trace metals [42], Chitosan binds to DNA by infiltrating into microorganisms , and interfers the synthesis of mRNA and protein [43], thereby inhibiting the production of toxins and the growth of microorganisms. Chitosan also can absorb metal ions or other chemicals, drugs (genes), deliver antibacterial and anti-tumor applications [43, 44].

On one hand, the anti-infective effect of the hydroxyapatite composite is to inhibit the cell membrane function by binding the complex of the double-doped hydroxyapatite to the cell membrane, thereby causing cytosol dissolution of the bacteria isolated from the cell wall. on the other hand, Bi interacts strongly with the the DNA, protein, which exist in bacteria, and interacts with sulfurphosphorus compounds exist in the outer membrane proteins, affect the respiratory chain response. Finally, This mechanism leads to cell death, hinders the synthesis of adenosine triphosphate (ATP), prevents cell wall synthesis, and inhibits a variety of enzymes, including urease, catalase and lipase [45].

\section{Conclusions}

In this paper, the characterization of Sr/CS/HA biocomposite material containing bismuth nanoparticles was investigated by SEM, XRD and FTIR. The scaffold shows a porous structure in the microscopic range, which is beneficial to cell infiltration and growing bone tissue. The bismuth element is distributed on the $\mathrm{Sr} / \mathrm{CS} / \mathrm{HA}$ matrix, inhibit the function of cancerous osteoblasts and promote the function of healthy osteoblasts. The $\mathrm{Bi} / \mathrm{Sr} / \mathrm{CS} / \mathrm{HA}$ material has increased swelling, compared to the Sr/CS/HA material within $24 \mathrm{~h}$. The increased antibacterial and bone proliferative properties of the scaffold are due to the presence of bismuth nanoparticles and these properties will help minimize implant-associated bacterial infections, promote bone formation, inhibit tumor growth. Therefore, this study shows that B3 stents will be more conducive to tissue engineering applications of bone defects after bone tumor surgery.

Acknowledgement. This work was funded by the National Key Research and Development Project (2017YFB0702600,2017YFB0702604).

\section{References}

1.J.K. ANNINGA, G. HANS, F. MARTA, J.R. KROEP, A.H.M. TAMINIAU, P.C.W. HOGENDOORN, E.J.E.J.o.C. R Maarten, Chemotherapeutic adjuvant treatment for osteosarcoma: where do we stand?, 47(16) (2011) 2431-2445.

2.K. MAYA, M.W. TENG, M.J. SMYTH, D.M. THOMAS, J Nature Reviews Cancer, Translational biology of osteosarcoma, 14(11) (2014) 722-735.

3.V.Y. JO, C.D.J.P. FLETCHER, WHO classification of soft tissue tumours: an update based on the 2013 (4th) edition, 46(2) (2014) 95-104.

4.R.J.J.L.O. GRIMER, Surgical options for children with osteosarcoma, 6(2) (2005) 85-92.

5.S.C. COX, P. JAMSHIDI, L.M. GROVER, K.K. MALLICK, Preparation and characterisation of nanophase $\mathrm{Sr}, \mathrm{Mg}$, and $\mathrm{Zn}$ substituted hydroxyapatite by aqueous precipitation, Mater Sci Eng C Mater Biol Appl 35 (2014) 106-14. 
6.M. LI, P. HE, Y. WU, Y. ZHANG, H. XIA, Y. ZHENG, Y. HAN, Stimulatory effects of the degradation products from $\mathrm{Mg}-\mathrm{Ca}-\mathrm{Sr}$ alloy on the osteogenesis through regulating ERK signaling pathway, Sci Rep 6 (2016) 32323.

7.F.J. MARTINEZ-VAZQUEZ, M.V. CABANAS, J.L. PARIS, D. LOZANO, M. VALLET-REGI, Fabrication of novel Si-doped hydroxyapatite/gelatine scaffolds by rapid prototyping for drug delivery and bone regeneration, Acta Biomater 15 (2015) 200-9.

8.Y. WANG, J. WANG, H. HAO, M. CAI, S. WANG, J. MA, Y. LI, C. MAO, S. ZHANG, In Vitro and in Vivo Mechanism of Bone Tumor Inhibition by Selenium-Doped Bone Mineral Nanoparticles, ACS Nano 10(11) (2016) 9927-9937.

9.L. QI, Z. XU, X. JIANG, Y. LI, M.J.B. WANG, M.C. Letters, Cytotoxic activities of chitosan nanoparticles and copper-loaded nanoparticles, 15(5) (2005) 1397-1399.

10.D. PORNPATTANANANGKUL, L. ZHANG, S. OLSON, S. ARYAL, M. OBONYO, K. VECCHIO, C.M. HUANG, L. ZHANG, Bacterial toxin-triggered drug release from gold nanoparticlestabilized liposomes for the treatment of bacterial infection, J Am Chem Soc 133(11) (2011) 4132-9.

11.G. SONG, C. LIANG, H. GONG, M. LI, X. ZHENG, L. CHENG, K. YANG, X. JIANG, Z. LIU, Core-Shell MnSe@Bi2 Se3 Fabricated via a Cation Exchange Method as Novel Nanotheranostics for Multimodal Imaging and Synergistic Thermoradiotherapy, Adv Mater 27(40) (2015) 6110-7.

12.E.I. RABEA, M.E. BADAWY, C.V. STEVENS, G. SMAGGHE, W. STEURBAUT, Chitosan as antimicrobial agent: applications and mode of action, Biomacromolecules 4(6) (2003) 1457-65.

13.S.F.D. DOS, J.D.O.P. BL, V. KUMAR, V.N. CARDOSO, S.O. FERNANDES, C.M. SOUZA, G.D. CASSALI, A. MOORE, D.E. SOSNOVIK, C.T.J.N. FARRAR, Evaluation of antitumor activity and cardiac toxicity of a bone-targeted ph-sensitive liposomal formulation in a bone metastasis tumor model in mice, 13(5) (2017) 1693-1701.

14.X. CHENG, Y. YONG, Y. DAI, X. SONG, G. YANG, Y. PAN, C. GE, X. CHENG, Y. YONG, Y.J.T. DAI, Enhanced Radiotherapy using Bismuth Sulfide Nanoagents Combined with Photo-thermal Treatment, 7(17) (2017) 4087-4098.

15.MEHRA H R. Proceedings of the National Academy of Sciences, India. Section B.[J]. Proceedings of the National Academy of Sciences India, 1940:100-118.

16.J.G. FERNANDEZ, D.E.J.A.F.M. Ingber, Bioinspired Chitinous Material Solutions for Environmental Sustainability and Medicine, 23(36) (2013) 4454-4466.

17.G.G. BRIAND, N.J.C.R. BURFORD, Bismuth compounds and preparations with biological or medicinal relevance, 99(9) (1999) 2601-2658.

18.***S.-B. H, A.O. P, O.R. M, B. S D, M. M D, B. T K, S.J.P. H A, Bismuth subsalicylate in the treatment of acute diarrhea in children: a clinical study, 87(1) (1991) 18-27.

19.***J.R.J.S.J.G.S. Lambert, Clinical Indications and Efficacy of Colloidal Bismuth Subcitrate, 26(sup185) (1991) 13-21.

20.M. SELVAKUMAR, P. SRIVASTAVA, H.S. PAWAR, N.K. FRANCIS, B. DAS, G. SATHISHKUMAR, B. SUBRAMANIAN, S.K. JAGANATHAN, G. GEORGE, S.J.A.A.M. Anandhan, Interfaces, On-Demand Guided Bone Regeneration with Microbial Protection of Ornamented SPU Scaffold with Bismuth-doped Single Crystalline Hydroxyapatite: Augmentation and Cartilage Formation, 8(6) (2016) 4086-4100.

21.GOVINDARAJ D, RAJAN M. Binary functional porous multi mineral-substituted apatite nanoparticles for reducing osteosarcoma colonization and enhancing osteoblast cell proliferation[J]. Materials Science and Engineering: C, 2017:S0928493116326169.

22.E. BONNELYE, A. CHABADEL, F. SALTEL, P.J.B. Jurdic, Dual effect of strontium ranelate: Stimulation of osteoblast differentiation and inhibition of osteoclast formation and resorption in vitro, 42(1) (2008) 129-138.

23.Y. LEI, Z. XU, Q. KE, W. YIN, Y. CHEN, C. ZHANG, Y.J.M.S. GUO, E. C, Strontium hydroxyapatite/chitosan nanohybrid scaffolds with enhanced osteoinductivity for bone tissue engineering, 72 (2017) 134-142. 
24.A. FONSECA-GARCÍA, J.D. MOTA-MORALES, Z.Y. GARCÍA-CARVAJAL, V.M. LÓPEZ, E. RUVALCABA, C. LANDA-SOLIS, I.A. QUINTERO-ORTEGA, L. SOLÍS, M.C. GUTIÉRREZ, M. TERRONES, Effect of doping in carbon nanotubes on the viability of biomimetic chitosan-carbon nanotubes-hydroxyapatite scaffolds, Journal of Biomedical Materials Research Part A 102(10) (2015) 3341-3351.

25.Y. LU, M. LI, High-activity chitosan/nano hydroxyapatite/zoledronic acid scaffolds for simultaneous tumor inhibition, bone repair and infection eradication, Mater Sci Eng C Mater Biol Appl 82 (2018) 225-233.

26.TRIPATHI A1, SARAVANAN S, Pattnaik S Bio-composite scaffolds containing chitosan/nanohydroxyapatite/nano-copper-zinc for bone tissue engineering. Int J Biol Macromol. 2012 Jan 1;50(1):294-9

27.MARTÍNEZ-VÁZQUEZ FJ1, CABAÑAS MV2, Paris JL Fabrication of novel Si-doped hydroxyapatite/gelatine scaffolds by rapid prototyping for drugdelivery and bone regeneration. Acta Biomater. 2015 Mar; 15:200-9

28.***I.A.a.I. Zainol, In situ synthesis and characterization of novel strontium doped nano chitosanhydroxyapatite composite. Der Pharma Chemica (2016) 8(14):25-32.

29.T.J. WEBSTER, E.A. MASSA-SCHLUETER, J.L. SMITH, E.B. SLAMOVICH, \%J Biomaterials, Osteoblast response to hydroxyapatite doped with divalent and trivalent cations, 25(11) (2004) 21112121.

30.D. GOVINDARAJ, M. RAJAN, M.A.J.R.A. Munusamy, Osteoblast compatibility of minerals substituted hydroxyapatite reinforced poly(sorbitol sebacate adipate) nanocomposites for bone tissue application, 5(55) (2015) 44705-44713.

31.D. GOVINDARAJ, M. RAJAN, M.A. MUNUSAMY, A. HIGUCHI, Mineral substituted hydroxyapatite coatings deposited on nanoporous $\mathrm{TiO} 2$ modulate the directional growth and activity of osteoblastic cells, RSC Adv .5 (2015) 58980-58988.

32.HERNANDEZ-DELGADILLO R1, GARCÍA-CUÉLLAR CM2, SÁNCHEZ-PÉREZ Y In vitro evaluation of the antitumor effect of bismuth lipophilic nanoparticles (BisBAL NPs) on breast cancer cells.Int J Nanomedicine. 2018 Oct 5;13:6089-6097.

33.J.J. GUAN, B. TIAN, S. TANG, Q.F. KE, C.Q. ZHANG, Z.A. ZHU, Y.P. GUO, Hydroxyapatite coatings with oriented nanoplate arrays: synthesis, formation mechanism and cytocompatibility, $\mathrm{J}$. Mater. Chem. B 3 (2015) 1655-1666.

34.A.H. AMBRE, D.R. KATTI, K.S. KATTI, J Journal of Biomedical Materials Research Part A, Biomineralized hydroxyapatite nanoclay composite scaffolds with polycaprolactone for stem cellbased bone tissue engineering, 103(6) (2015) 2077-2101.

35.H. LIU, H. PENG, Y. WU, C. ZHANG, Y. CAI, G. XU, Q. LI, X. CHEN, J. JI, Y.J.B. ZHANG, The promotion of bone regeneration by nanofibrous hydroxyapatite/chitosan scaffolds by effects on integrin-BMP/Smad signaling pathway in BMSCs, 34(18) (2013) 4404-4417.

36.L.R. AMIR, D.F. SUNIARTI, U. SRI, A.J.C. BASRIL, T. Research, Chitosan as a potential osteogenic factor compared with dexamethasone in cultured macaque dental pulp stromal cells, 358(2) (2014) 407-415.

37.O. YASUHISA, O.J.C.C. KEIICHI, [Bone and Stem Cells. The mechanism of osteogenic differentiation from mesenchymal stem cell], 24(4) (2014) 501-8.

38.J. XU, Z. LI, Y. HOU, W.J.A.J.O.T.R. FANG, Potential mechanisms underlying the Runx2 induced osteogenesis of bone marrow mesenchymal stem cells, 7(12) (2015) 2527.

39.N. CHATTOPADHYAY, S.J. QUINN, O. KIFOR, C. YE, E.M.J.B.P. BROWN, The calciumsensing receptor (CaR) is involved in strontium ranelate-induced osteoblast proliferation, 74(3) (2007) 438-447.

40.E.R. PEGO, I. FERNÁNDEZ, M.J.J.U.O.S. NÚÑEZ, O. Investigations, Molecular basis of the effect of MMP-9 on the prostate bone metastasis: A review, (2018) S1078143918300851. 
41.GOVINDARAJ D, RAJAN M. Binary functional porous multi mineral-substituted apatite nanoparticles for reducing osteosarcoma colonization and enhancing osteoblast cell proliferation[J]. Materials Science and Engineering: C, 2017:S0928493116326169.

42.D. CELIS, M.I. AZOCAR, J. ENRIONE, M. PAEZ, S. MATIACEVICH, Characterization of salmon gelatin based film on antimicrobial properties of chitosan against E. coli, Procedia Food Science 1(1) (2011) 399-403.

43.ENTSAR I. RABEA, MOHAMED E.-T. BADAWY, CHRISTIAN V. STEVENS, +, a. Guy Smagghe, W.S.J. Biomacromolecules, Chitosan as antimicrobial agent: applications and mode of action, 4(6) (2003) 1457.

44.P. DISSAYA, Z. LI, O. SAGE, A. SANTOSH, O. MARYGORRET, V. KENNETH, H. CHUNMING, Z.J.J.o.t.A.C.S. Liangfang, Bacterial toxin-triggered drug release from gold nanoparticlestabilized liposomes for the treatment of bacterial infection, 133(11) (2011) 4132-9.

45.M. SELVAKUMAR, P. SRIVASTAVA, H.S. PAWAR, N.K. FRANCIS, B. DAS, G. SATHISHKUMAR, B. SUBRAMANIAN, S.K. JAGANATHAN, G. GEORGE, S. ANANDHAN, S. DHARA, G.B. NANDO, S. Chattopadhyay, On-Demand Guided Bone Regeneration with Microbial Protection of Ornamented SPU Scaffold with Bismuth-Doped Single Crystalline Hydroxyapatite: Augmentation and Cartilage Formation, ACS Appl Mater Interfaces 8(6) (2016) 4086-100

Manuscript received: 11.01 .2020 